\title{
Internal organizational communication, applicable to home office, in the company
}

\section{Comunicación interna organizacional, aplicable ante home office, en la empresa}

\author{
HERNÁNDEZ-FLORES, María Juana*† \& CRUZ-RAMIREZ, Erik Santiago \\ Tecnológico Nacional de México/Tecnológico de Estudios Superiores de Ixtapaluca \\ ID $1^{\text {st }}$ Author: María Juana, Hernández-Flores / ORC ID: 0000-0002-1179-1966, CVU CONACYT ID: 719745 \\ ID $1^{\text {st }}$ Author: Erik Santiago, Cruz-Ramirez / ORC ID: 0000-0002-4754-0886
}

DOI: $10.35429 / J I O .2021 .8 .5 .21 .31$

Received March 28, 2021; Accepted June 20, 2021

\begin{abstract}
For companies today it is necessary to have an avantgarde competitiveness, which can adapt to any activity to be undertaken by companies, that is why the internal organizational communication, applicable to the home office, seeks through the viability of the design of an organizational communication plan in the small digital company, obtain greater control and management of internal communication by employees, thereby strengthening the relationship of employees and their corporate culture. A case study is applied, through which the methodology established for this research is distinguished, initially giving a guideline to the previous analysis, problems of time management, staff needs to communicate, interview results and survey to build a benchmarking analysis matrix, as well as the development and implementation of a communication plan. The contribution that this work, is the efficiency of communication through the optimal use of communication technologies (ICT).
\end{abstract}

Efficient Communication, Home Office, Communication Technologies

\begin{abstract}
Resumen
Para las empresas hoy en día es necesario contar con una competitividad vanguardista, la cual pueda adaptarse a cualquier actividad a emprender por las empresas, por eso la comunicación interna organizacional, aplicable ante el home office, busca a través de la viabilidad del diseño de un plan de comunicación organizacional en la empresa DIGITAL de tamaño pequeña, obtener un mayor control y manejo de la comunicación interna por parte de los colaboradores, con ello se lograra el fortalecimiento de la relación de los colaboradores y su cultura corporativa. Se aplica un estudio de caso, por medio del cual se distingue la metodología que para esta investigación se establece, dando pauta de manera inicial al análisis previo, problemáticas de la administración del tiempo, necesidades del personal para comunicarse, resultados de la entrevista y encuesta para construir una matriz de análisis de Benchmarking, así como el desarrollo e implementación de un plan de comunicación. La contribución que este trabajo, es la eficiencia de comunicación a través del uso óptimo de las tecnologías de la comunicación (TIC).
\end{abstract}

Comunicación Eficiente, Home Office, Tecnologías de Comunicación

Citation: HERNÁNDEZ-FLORES, María Juana \& CRUZ-RAMIREZ, Erik Santiago. Internal organizational communication, applicable to home office, in the company. Journal-Industrial Organization. 2021. 5-8: 21-31

\footnotetext{
*Correspondence to Author (maria.hf@ixtapaluca.tecnm.mx)

$\uparrow$ Researcher contributing first author.
} 


\section{Introduction}

In the companies two aspects are defined: external and internal, the external ones defined from the clients that can be captured while the internal ones are those who develop the internal mobility of the organisation; for that reason from the functionality of the internal aspects, the organisational communication is one of the fundamental factors in the operation of the company, considered as central axis for the development of the activities, in this way it is established that, if a better communicative relation of the internal thing exists it will be reflected in external public, which contributes to create an image and identity that propitiates the effective networks of communication.

Nowadays, it is essential for every company to have an organisational communication plan, which functions as a guide for an adequate communication system, seeking to make the tasks more efficient. In addition, due to globalisation, it is necessary to advance day by day, by implementing the application of technology, focusing specifically on the application of information and communication technologies (ICT). Given the demands of the year 2020 due to the contingency, it is necessary to adapt to digital media and work in the distance mode, so having communication tools will be of great use to the organisation through the effectiveness that the communication plan can provide.

This research is applied in a small-sized company, with technological business activities, mainly dedicated to solutions in the planning of marketing strategies through digital media by means of marketing and design. Although the company, based on its line of business, possesses technologies for its productivity, according to the diagnosis carried out in DIGITAL, the communication that is generated in a remote system is distorted for the company's collaborators. For this reason and as part of the continuous improvement for the company, it is necessary to establish the following alternative hypothesis (Ha): If the internal control of organisational communication has an efficient influence on the performance of the collaborators, then the orientation of the objectives will be facilitated by monitoring and evaluating the internal processes of the Digital company. It should be noted that for reasons of confidentiality the name is omitted, but it will be referred to as Digital.
The research seeks to strengthen human capital through the organisational communication plan, focusing on the communication channels, since if there is a sender and a communication channel with the right message, the information that the receiver generates will be appropriate, in the search to make this communication more efficient. Therefore, the information developed focuses initially on the guideline that can generate a planning through the communication plan that needs to be structured in the company, and secondly, the efficiency of communication with the Home Office.

This helps to section the information to develop through 5 points, addressed as follows: in point one, the guideline that seeks to generate establish a comprehensive communication plan in the company, in point two determines the competitiveness in communication to the Home Office, in point three establishes the advantage to establish a communication system to the Home Office, while point four gives the guideline to effective communication strategies to the Home Office, finally generating the structure that applies to a communication plan, to the Home Office, in the company DIGITAL

\section{Description of the method}

\section{Guideline for the internal communication plan in the company}

To achieve a good guideline, through which you can use effective communication within the company, it is required that this is efficient, which is why the theory of Efficient Communication is considered the premise that the organization is a system generated through the interaction of interrelated elements, such as the communication process through efficient communication to perform tasks or activities effectively to Home Office. By means of the efficiency in the communication environment, better results for the company will be found, focusing on the best performance and increase of the percentage of profits on the part of the company. Through the Home Office and by means of the employees, the aim is to maintain or increase the results that the company requires; in this way, to promote a remote working environment in accordance with the context and the resources that the employees have. 
As already mentioned in the introductory section, the organisation needs to work together, the internal part made up of the employees and the external part made up of the service provided to the client, which is why, according to the author Fernández Collado (FERNÁNDEZ, 1999), who defines internal communication as: The set of activities carried out by any organisation for the creation and maintenance of good relations with and among its members, through the use of different means of communication that keep them well informed, integrated and motivated to contribute with their work to the achievement of organisational objectives. From the perspective of (FERNÁNDEZ, 1999), external communication is the set of messages issued by any organisation to its different external audiences.

Therefore, by distinguishing between these two important starting points (internal and external) to generate effective communication, the forms, channels and tools are highlighted, under which an adequate message is generated for the functionality of the activities developed in the company, considering the structure of a communication plan, The information is based on the theory of the $\mathrm{X}$ and $\mathrm{Y}$, focusing on the importance of the systems and processes that the organisation has and the availability of human capital, seen as a set of elements necessary to apply effective communication strategies for the Home Office, and its expansion is described in the following section.

As mentioned in the introduction, the contingency established in 2020 led companies to implement a home working system as a result of which they did not have the necessary preparation or the appropriate resources. Thus, for the company Digital, dedicated to the generation of marketing projects, among which stand out the advertising campaigns to various renowned companies, both public and private, obtaining results of 357 successful campaigns, a reach of 5 million people and 111 websites, this achieved in an in-person system prior to the contingency. For the Digital company, it is essential to have a digital tool to implement the activities to be developed internally; for the collaborators it was complex to use the technological systems, as it required careful supervision for the approval of the projects as well as the contribution of new ideas or feedback from the work teams.
Therefore, an efficient communication plan that could guide communication in a virtual situation, carried out remotely, began to be cemented, starting with a study to find out what was available and what had to be improved for the continuous improvement of internal performance and satisfaction of the clients with whom we were working at that time, without forgetting the attraction of new clients.

\section{Determining competitiveness in communication with the Home Office}

Companies always seek to stand out in the market for products and services, for which it generates competition against others in the same line of business or industry, but not all companies can develop competitiveness because it requires highlighting practices that make it different from others. For the digital company it is very important to generate its own competitiveness, for this it is necessary to know what it has and what other companies offer as immediate competition.

As mentioned in the previous section, the theory of the $\mathrm{X}$ and $\mathrm{Y}$, as a structural principle of the communication plan, achieving within the plan, to establish effective communication strategies before the Home Office; therefore, figure 1 is analysed, where part of the theory of the X-Y of Taylor and Douglas McGregor is shown; In the $\mathrm{X}$ section, the search for work efficiency, achieved through the activities that establish the productivity of the company, from any of the areas, fulfilling a business objective, thus achieving greater performance of the areas and collaborators, which leads to lower costs (time and movements), from the perspective of work specialisation, as part of labourprofessional growth. While the Y theory section, marks a humanistic approach, which allows to identify the particular course determining satisfaction and individual growth by the collaborator, for this it is required to develop in the collaborator a labour autonomy, in the search for better results, thus instilling responsibility for the company and the activities that unfolds in the same organisation.

The X-Y theory gives a glimpse of the fact that competitiveness is managed by the internal part of the company, due to the fact that human capital is what moves and generates the functionality of the organisation. 
The X-focused theory is distinguished as follows: the X-focused theory evaluates the performance since the activities to be carried out in the area or organisation are communicated; while the Y-focused theory focuses on the part of responsibility, placing the organisation (timespace) working autonomously, both theories would evaluate the efficiency of the communication of the tasks entrusted to the functionality of the department (Figure 1).

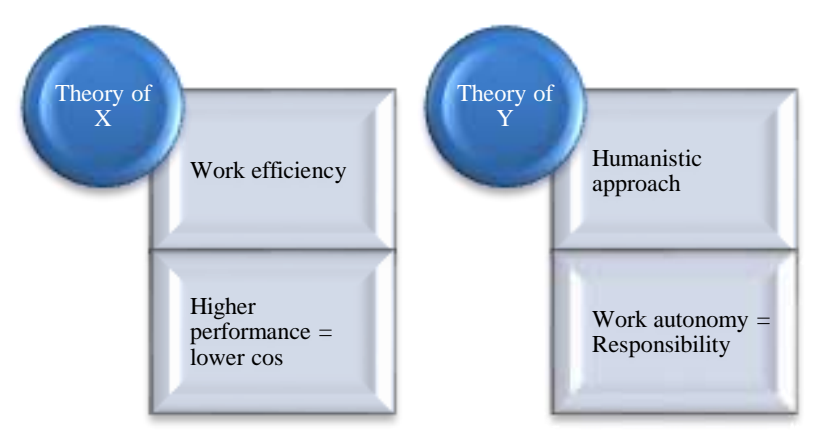

Figure 1 Theory of X - Y "Competitiveness of communication vis-à-vis the Home Office"

Source: Elaborated by Hernández Flores. (2020)

From the previous theory of the X-Y, it is distinguished that the performance assigned to employees in different areas and tasks requires strategies that help to improve work performance and the use of the correct communication channels, so that efficient work performance is achieved.

Following the aforementioned theory, the analysis of the Digital Company is generated through the SWOT Matrix, in order to determine key points that emphasise the continuous improvement of the company, making use of a Communication Plan as the main strategy.

As can be seen in Table 1, in the section on strengths, the company has tools such as Information and Communication Technologies (ICTs), which can be reinforced by making more use of them as a competitive advantage; likewise in the section on opportunities, where points that can be strengthened to boost the company's growth are described.

The weaknesses and threats can strengthen the organisation, with a view to strengthening Digital in the administrative and efficient communication areas.
For Digital, as part of the SWOT analysis, communication, positioning, professional preparation of its employees, customer satisfaction and tangible objectives are part of its strengths, which it wants to expand through opportunities, focused on adapting to business changes, customer loyalty and customer acquisition, as well as undertaking social challenges. Without leaving aside the weaknesses that can be transformed through the implementation of company policies, establishment of the organisational culture, determination of the organisational structure coordinating tools for the modality of work at home. Taking into account the threats that may be latent through the increase of competition in the digital era, causing the emergence of regulations for companies in the digital sector, which would trigger an increase in prices on digital platforms. This analysis determined by means of the SWOT that emanates from DIGITAL, highlights points of improvement that can evolve into areas of opportunity with an impact on business growth. (See table 1)

\begin{tabular}{|c|c|}
\hline \multicolumn{2}{|c|}{ FODA } \\
\hline Strengths & Weaknesses \\
\hline $\begin{array}{l}\text { - Communication is handled } \\
\text { through digital media. } \\
\text { - The positioning of the } \\
\text { company is quite remarkable. } \\
\text { - The company's human talent } \\
\text { has a high level of knowledge } \\
\text { and a great track record in } \\
\text { experience. } \\
\text { - It has a good track record of } \\
\text { satisfied customers. } \\
\text { - It has good projects and long- } \\
\text { term goals for the work team. }\end{array}$ & $\begin{array}{l}\text { - There are no policies for } \\
\text { communication management. } \\
\text { - It does not have a well-defined } \\
\text { organizational culture. } \\
\text { - It does not have an effective } \\
\text { organizational structure. } \\
\text { - It does not have tools for the } \\
\text { work-at-home modality. }\end{array}$ \\
\hline Opportunities & Threats \\
\hline $\begin{array}{l}\text { - Over time, the company can } \\
\text { become stronger and adapt to } \\
\text { new trends and changes. } \\
\text { - There is a high demand for its } \\
\text { services in the market. } \\
\text { - The changes caused by the } \\
\text { Covid-19 pandemic, can be a } \\
\text { great growth opportunity for } \\
\text { digital companies. }\end{array}$ & 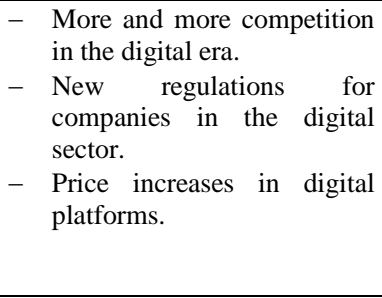 \\
\hline
\end{tabular}

Table 1 SWOT Matrix of the company DIGITAL

Source: Prepared by Cruz Ramírez Erick Santiago (2020), with data from DIGITAL

Therefore, this matrix of the company Digital, can give different changes to the organisation, from the way of working, to the way of communication. From the SWOT analysis it is considered to carry out a survey, directed to the collaborators of the company, in which it is sought to establish three moments: 1) face-to-face context, 2) the mixed and 3) at a distance; managing to distinguish in which of them will be more optimal the performance. 


\section{Advantage of establishing a system of communication with the Home Office}

A communication system that lacks efficiency is very difficult to maintain, due to the constant mistakes that are made, for not having and following an adequate communication channel, supported through an internal analysis of the company. Digital, as already mentioned, has a turn focused on the technology market, but at the time the communication and information technologies (ICT's) were relegated to the internal environment of the company, as the roles and actions corresponding to the service process that the company provides were executed in person.

But during the year 2020 that is forced to work remotely due to the contingency, it becomes noticeable through the SWOT, that the systematisation of the work organisations, were distorted in the Home Office system, because initially there was a lack of strategies and only handled an experimental phase, to determine the appropriate means applicable in the process of internal communication; with the passage of time were knowing which were the most suitable channels of communication and platforms for sending information more feasible, however factors that also influenced this process were glimpsed being these: The lack of learning or knowledge on the part of the collaborators, the lack of specialisation on the part of the leaders (area managers), as well as the tactics for the delegation of tasks that led to the fulfilment of the company's objectives.

A quantitative investigation was carried out in order to identify what could be improved in the company. For this purpose, we structured items that would show, through questions addressed to the leaders and collaborators, points of improvement that would lead to actions that would benefit Digital. In graph 1 it can be seen that the moments that are considered are measured from the headings of a) performance (skills and abilities, training to increase knowledge and improve work through supervision or review of activities); b) influencing factors (influencing factors such as indications (activities), place or work space and external factors); c) form of work (focused on adaptability and availability, to perform activities remotely or in a mixed way).

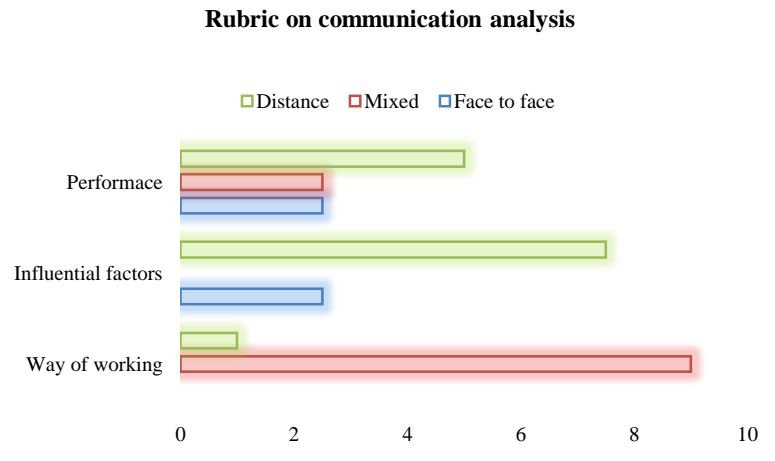

Figure 1 Communication items Source: Prepared by Cruz Ramírez Erick Santiago and Hernández Flores María Juana with data from DIGITAL

As can be seen in graph 1, the way of working and the way of establishing internal communication are points that will determine the possibility of carrying out business tasks, both in a mixed system and remotely, these two scenarios being favourable for the organisation. Taking into consideration these scenarios and moments for the development of the work, key points for internal communication can be distinguished, broken down in the Communication Plan, which will be established on the basis of: 1) activities assigned to each area or collaborator, 2) improvement of activities through knowledge, applied to work practice and 3) accompaniment of collaborators, guided by the person in charge of the area and feedback from the work team.

From the results of this research, based on the quantifiable analysis items by the collaborators that make up the Digital company, the advantages that could be developed by the communication proposed in the three moments defined as face-to-face, distance or mixed are supported.

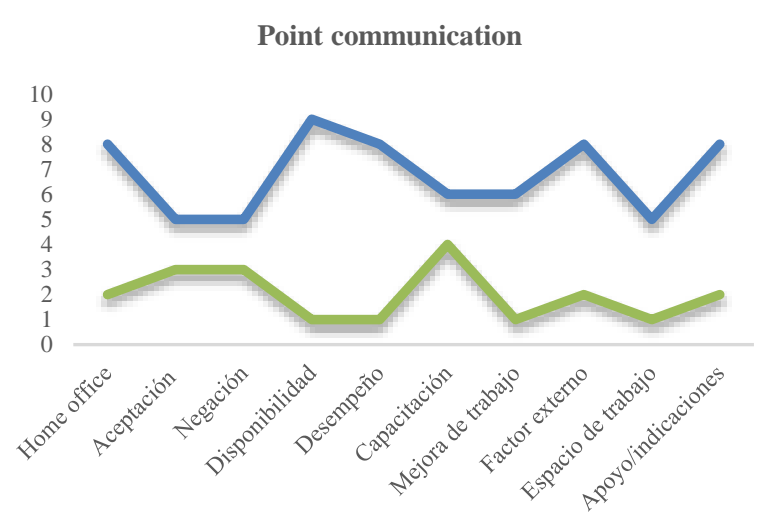

Figure 2 Points for internal communication Source: Elaborated by Hernández Flores (2020) 
As shown in Graph 2, the linear sequence at the top shows the advantages of developing work through the home office either remotely or mixed, while the linear sequence at the bottom highlights the few possibilities that could be had in terms of business growth by returning to the face-to-face method.

The competitiveness of the company under the home office communication system can become outstanding for the company in a contingency situation, showing itself to be at the forefront in terms of the use of technological tools and efficient strategies that boost the company's growth.

\section{Results}

\section{Structure that is applied to a communication plan, before the Home Office, in the DIGITAL company}

In order to generate a comprehensive communication plan, it was necessary to apply an analysis, which consists of using the benchmarking matrix, a technique used to analyse other companies seen as competitors. This analysis aims to compare the following: a) how they carry out administrative processes, b) distinguish their way of working, c) tools and technology used; by applying the Benchmarking Matrix, the aim is to distinguish the points of improvement of the Digital Company, in order to be more competitive and to fulfil its vision of being the best in its field.

The analysis of the Digital Company considers the immediate direct competition, represented by some digital marketing agencies in Mexico City, the analysis focuses specifically on the social networks of the companies, because they are the means by which they communicate the general activities that are being carried out both internally and externally; in this way it is possible to obtain points of improvement that is undoubtedly an important factor for the company.

Table 2 is shown below, in which we can see in the columns the companies that are analysed, described as Digital, Competence 1 and Competence 2; while in the rows are located the items under which the work of competitive impact is focused, developed by each of the companies, thus providing relevant information for the structure of the communication plan.

\begin{tabular}{|c|c|c|c|}
\hline Company & DIGITAL & Competence 1 & Competence 2 \\
\hline $\begin{array}{l}\text { What is it? } \\
\text { (strategic } \\
\text { approach) }\end{array}$ & $\begin{array}{l}\text { Plan strategies } \\
\text { according to the } \\
\text { business } \\
\text { objectives of } \\
\text { each of our } \\
\text { clients. }\end{array}$ & $\begin{array}{l}\text { Generate } \\
\text { digital } \\
\text { advertising } \\
\text { strategies } \\
\text { focused on } \\
\text { results. }\end{array}$ & $\begin{array}{l}\text { Create } \\
\text { strategies and } \\
\text { experiences } \\
\text { focused on the } \\
\text { growth of your } \\
\text { brand. }\end{array}$ \\
\hline $\begin{array}{l}\text { Website } \\
\text { analysis (what } \\
\text { aspects you } \\
\text { handle of your } \\
\text { organization) }\end{array}$ & $\begin{array}{l}\text { Quality work } \\
\text { before } \\
\text { customers. }\end{array}$ & $\begin{array}{l}\text { Degree of } \\
\text { training of its } \\
\text { workers. }\end{array}$ & $\begin{array}{l}\text { Quality } \\
\text { emphasizing } \\
\text { teamwork. }\end{array}$ \\
\hline $\begin{array}{l}\text { Analysis of } \\
\text { social networks } \\
\text { (content } \\
\text { focused on } \\
\text { your } \\
\text { organizational } \\
\text { structure). }\end{array}$ & $\begin{array}{l}\text { Management of } \\
\text { service } \\
\text { information, } \\
\text { focused on } \\
\text { Instagram. }\end{array}$ & $\begin{array}{l}\text { Its Instagram } \\
\text { network } \\
\text { handles content } \\
\text { related to its } \\
\text { staff, as well as } \\
\text { the design of } \\
\text { the } \\
\text { workstation, } \\
\text { while on } \\
\text { Facebook it } \\
\text { only handles } \\
\text { informative } \\
\text { content. }\end{array}$ & $\begin{array}{l}\text { On the website } \\
\text { if they reflect } \\
\text { more their } \\
\text { organizational } \\
\text { way of } \\
\text { working. }\end{array}$ \\
\hline Key points & $\begin{array}{l}\text { Focus your } \\
\text { activities on the } \\
\text { home office. }\end{array}$ & $\begin{array}{l}\text { Concrete } \\
\text { content putting } \\
\text { quality first. }\end{array}$ & 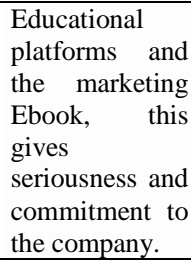 \\
\hline $\begin{array}{l}\text { Similarities of } \\
\text { the type of } \\
\text { approach }\end{array}$ & $\begin{array}{l}\text { It specializes in } \\
\text { very specific } \\
\text { niches, however } \\
\text { it has a } \\
\text { resemblance to } \\
\text { Competition 1, } \\
\text { for the type of } \\
\text { content that was } \\
\text { handled in its } \\
\text { beginnings, } \\
\text { residing here, } \\
\text { that competitive } \\
\text { advantage. }\end{array}$ & $\begin{array}{l}\text { The work on } \\
\text { Instagram is } \\
\text { similar with } \\
\text { Digital, } \\
\text { although it later } \\
\text { takes another } \\
\text { approach. }\end{array}$ & $\begin{array}{l}\text { It takes more } \\
\text { into account its } \\
\text { staff, in } \\
\text { addition its } \\
\text { Ebook and } \\
\text { certification } \\
\text { give it that plus. }\end{array}$ \\
\hline
\end{tabular}

Table 2 Competence Benchmarking Matrix Analysis SOURCE: Prepared by Cruz Ramírez Erick Santiago(2020)

The analysis of the Benchmarking Matrix shows that internal efficiency is achieved by strengthening the communication channels applicable to the Home Office, which will be reflected in the best practices of external communication using the planning of strategies in line with the business objectives of each of the customers, delivery of quality work for customers, as well as the management of information services through social networks such as Instagram. The Digital Company seeks a competitive advantage through electronic media, using efficient internal and external communication, because it specialises in very specific niches. The structure for the communication plan, which will serve to optimise the resources available to the Digital company, mainly the human and technological resources of the Home Office, can be understood from here. 
The Communication Plan for the Digital company consists of establishing improvements in the control of internal communication between the work team, applied in a hierarchical way in the home office work modality; detecting different needs as well as difficulties in establishing adequate internal communication, thus favouring home office work in a correct way, in: the structure, the organisational culture and philosophy, as well as the tools and platforms used for communication.

In order to base the Communication Plan, use is made of different models to be applied in the Digital company, taking into account the SWOT analysis matrix (table 1) and the benchmarking matrix (table 2), supporting the structure of the plan, showing through the two matrices, the current situation of the company; use is also made of research techniques such as the survey and the interview, to find out the needs of the staff, allowing to focus on the most latent problems of the company. A pilot is carried out to provide feedback, applying evaluations, diagrams and models that allow the development of the plan.

Scheme 1 shows the structure of the process of implementation and integration of the Communication Plan, which is composed in the header of the table with a sequence of InputProcess-Output; the development of the flowchart describes each activity to be carried out by means of the symbolisms that it handles.

As mentioned above, the diagram expresses in its input part the identification of the problems regarding the effectiveness of communication, supporting the diagnosis of the main problems. The process section shows the application of the analysis through the matrices, as well as the research instruments (survey and interviews) applied to the collaborators; both the matrices and the instruments, determining the areas of opportunity to work on in the company. Finally, in the output section, the strategies to generate effective communication are implemented.

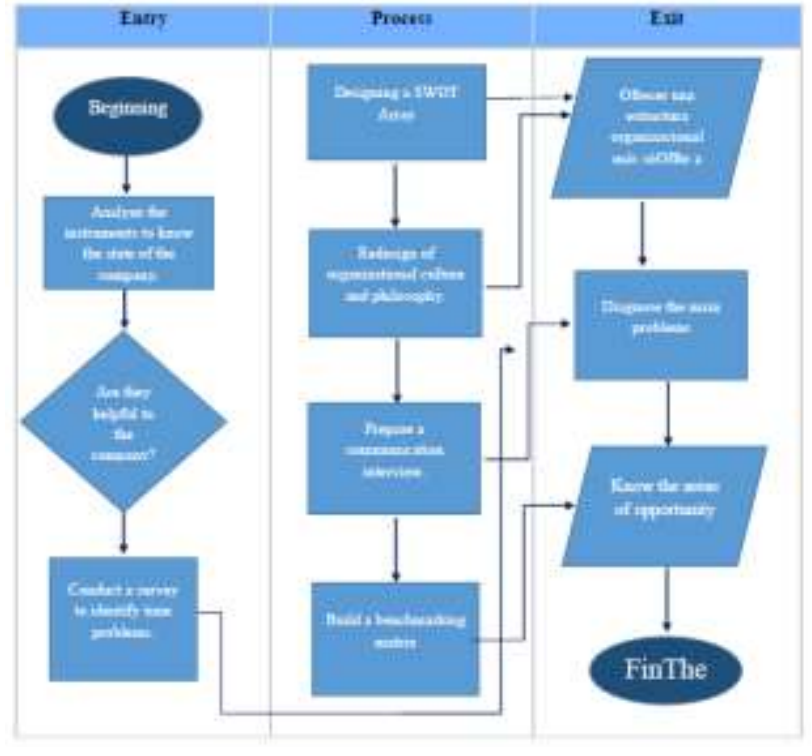

Figure 3 Flowchart of the process of developing a communication plan

Source: Own elaboration with data from the survey applied in the SKYGROOVE DIGITAL company

One of the benefits that this communication plan brings to the company is to improve the planning and organisation of activities, so that employees know what is going to be done considering: 1) to be clear about the direction of the work assignments, 2) to foresee each of the aspects that each task must have in order to achieve the objectives, 3 ) to know who is going to carry out the activities (improving communication and delegating tasks to the work team). Following the administrative structure in the management part of the communication channels, those involved in the plan contribute to the achievement of objectives, having the power to improve the motivation and leadership of each of the collaborators. Finally the control will help to follow up the plan, to get feedback and to reflect the continuous improvement within the company.

\section{Methodology}

\section{Effective communication strategies for the Home Office}

Internal communication strategies can be effective, as long as the right channels of communication are established, the right message is transmitted in the communication process, but above all the guidance through which employees feel confident to perform their work to the best of their ability. Scheme 2 establishes three aspects on which it is proposed to develop communication strategies. 
It is understood that efficient communication must be based on knowing how to transmit each of the activities, with the pertinent indications giving rise to minimising doubts on the part of the collaborator. With regard to the application of the home office, it is important to take into consideration that activities carried out remotely will generate doubts when they are executed, so in order to achieve good performance and fulfilment of objectives, the tasks must be backed up by the support of the hierarchically established authorities, facilitating the employee's performance. The third, focused on the use of technologies, is to be able to count on advantages for the reduction of costs, determining an investment but with great profits.

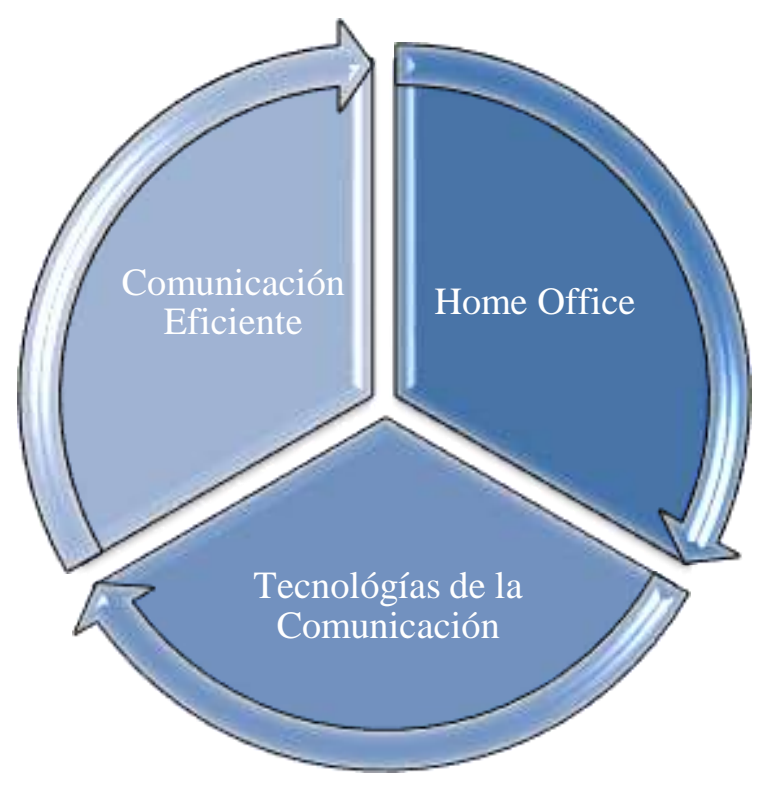

Fugure 4 Strands for communication strategies Source: Elaborated by Cruz, Ramírez Erick Santiago and Hernández Flores María Juana. (2020)

Starting from these aspects as strategies, the Home Office, Communication Technologies and Efficient Communication, it can be considered the adequate channel to make an activity functional; considering that the home office will represent for the Digital company a competitive advantage in the internal and external environment of the company, at the moment of making use of the technologies making an efficient communication; important points to establish as a structural guide of a strategic communication plan, before the home office.

\section{Methodological process applied to the Internal Communication research}

This research considers the independent variable through the plan, as it is a strategic part of the project, influencing the objectives, strategies, tools and organisational communication, applicable to the problems posed. In addition, the plan, through its structure, defines the meaning of the research, designing each of the parts for its implementation in organisational communication.

The dependent variable, worked through organisational communication, measures the performance within the company, considering the effective functionality in the organisation.

Therefore, the research design, making use of different techniques, such as data collection, in order to collect the required information based on the problem posed, through instruments designed and applied to the collaborators (leaders and staff) of the Digital Company. This research allowed the collection of quantitative and qualitative data, by means of interviews and surveys; getting to know more concretely the opinions of the people who work in this company, which made it possible to obtain different points of view from the perspectives of the hierarchical levels.

Through these instruments key information was collected, which was used to generate a decision making process that emphasised the improvement of internal communication in the company, and also helped to evaluate what strategies and tools could be implemented to obtain a technological benefit that would make Digital's communication with the Home Office more efficient.

In order to calculate the sample, statistical methods were applied, which allowed us to obtain the necessary information for the development of this research; highlighting that the initial calculation of the population is affected by the current pandemic (COVID-19), due to the fact that the number of respondents and interviewees was reduced, due to an internal problem of the company. 
The Digital company is composed of a work team that hierarchically is composed of leaders and staff, through which the characteristics of the participants who were part of this research are generated, highlighting that each of them has a great experience in digital marketing as well as an average experience of 4 years in this area, they have knowledge about design, content creation and people specialised in web development, in addition to recognising that they are experts in the management of data analysis tools such as google ads, semrush, google analitycs, among others.

The sampling procedure seeks to know how many employees will be surveyed, being these who provide data on the problems of the company, through statistical calculations will have greater accuracy in the analysis and recommendation for an assertive decision making on the results obtained.

Formula:

$$
n=\frac{N \bullet Z \bullet P \bullet(1-P)}{(N-1) \bullet e^{2}+Z^{2} \bullet P \bullet(1-P)}
$$

\section{Substitution of the population formula}

$$
\begin{aligned}
& \mathrm{n}=i ? \\
& \mathrm{~N}=13 \\
& \mathrm{Z}=95 \%=1.96 \\
& \mathrm{P}=50 \%=0.5 \\
& \mathrm{e}=3 \%=0.03 \\
& n=\frac{13 * 1.96 * 0.5(1-0.5)}{(13-1) 0.03^{2}+1.96^{2} * 0.5(1-0.5)} \\
& n=\frac{13 * 1.96 * 0.5(0.5)}{(12) 0.0009+3.8416 * 0.5(0.5)} \\
& n=\frac{6.37}{0.0108+0.9604} \\
& n=\frac{6.37}{0.9712} \\
& n=7 \text { Entrevistas y Encuestas }
\end{aligned}
$$

After making the relevant calculation of the sample, it is obtained that of the total population of 13 workers, a sample of 7 collaborators is considered, in order to carry out the application of the proposed interviews.
On the other hand, a greater veracity of the information is considered, which is why the decision was taken to consider the population, due to the fact that the company, as a result of the contingency, presented a notable reduction in the workforce.

The procedure for measuring variables and collecting data is done by means of the analysis of statistical results through the processing of data from the application of the surveys; as a result of the interview, an analysis is carried out through the answers provided by the study population. For both cases, the information on the criteria that influence the home office is considered to be grouped, so that strategies can be implemented in the company, so that the team of collaborators can develop and improve their performance in remote work.

\section{Acknowledgement}

The Tecnológico Nacional de México (TecNM), through our institution, the Tecnológico de Estudios Superiores de Ixtapaluca (TESI), seeks to be in constant contact with the productive sector, thanks to which the development of this research is possible. To the participation of each one of the collaborators of the company Digital, who gave the facilities for the compilation of the information. We are also grateful to the people who, through their human warmth and support, have made this achievement possible.

\section{Conclusions}

In the companies it is necessary to carry out an efficient communication, because this will impact in great measure in the activities that are executed internally and externally, it is for that reason that the proposal to generate a Plan of Organisational Communication for the company Digital, was a decision that was taken in reference to the deficiencies and needs that were detected in the way of communicating and managing tasks, due to the fact that there was a transition from face-to-face work to the home office modality, which was a complex process, since at the beginning of the company the minority of collaborators did not work in this modality at the time. 
The company's employees, being in contact through digital platforms, identified ways or strategies to provide solutions to the problems they faced when working remotely, which was not enough, as it was necessary to make use of tools to support the accurate detection of the problems, so a methodological process was generated for the development of a Plan, which initially establishes an analysis, then a proposal of strategies, focused on possible solutions and finally a documented functional structure of the Communication Plan for the Digital company.

Within this research it was vital to know the communication needs, because it was detected as a problem, the deficiency in the control of internal communication in the Digital company, therefore a solution of value was sought, based on the Hypothesis of alterna (Ha) described below: Yes, the internal control of organisational communication influences efficiently in the performance of employees, then, it will facilitate the orientation of the objectives by monitoring and evaluating the internal processes of the Digital company. Obtaining very satisfactory results, generating different proposals or alternative solutions, creating instruments applicable to the case, which were of great help in identifying all the situations for improvement, giving guidelines to propose instruments that will help to establish strategies as part of a competitive advantage.

When the research study and the design of the instruments for the improvement of communication were carried out, the communication plan was proposed, which had the following goals: to improve the remote work in search of meeting the objectives, so that the company could obtain a better development and growth in the field of digital marketing.

Through this it was possible to empower the organisation in the management of communication, since nowadays many companies face unexpected changes such as taking the work to another modality, however many of them are not prepared to exercise the work as a Home Office and tend to become extinct for not supporting such radical changes, therefore the results obtained regarding the communication plan are crucial for the Digital company and some other companies, to continue in operation and above all to adapt to changes.

\section{References}

Carlos, F. C. (1999). La comunicación en las organizaciones. México: Trilla

Castillo Ramírez, Y. A., \& Suárez Ruiz, M. C. D. S. (2021). Valoración de la comunicación interna de las universidades privadas de Piura por sus trabajadores, 2020.

Centro de Estudios Financieros (2019) El Plan de Marketing en la empresa. Recuperado de: https://www.marketing-xxi.com/el-plan-demarketing-en-laempresa-132.htm 28 de septiembre de 2019

Chaname Quevedo, O. G. (2021). Endomarketing para el compromiso organizacional del personal administrativo de una universidad privada en la ciudad de Chiclayo.

Charles W. Lamb Jr. (2002). Marketing. Editorial Thomson, 6ta Edición, México.

González Urbina, M. A., \& Castro Meneses, J. A. (2021). Proyecto: Smart Bio House.

Padilla R. (2018). Philip Kotler: Padre del Marketing. Recuperado de: https://www.genwords.com/blog/philip-kotlerpadre-del-marketing. Consulta: 24 de septiembre de 2019

Philip Kotler, (2018). Dirección del Marketing, Editorial McGraw, 1ra Edición, México 2004. Recuperado de: https://www.lahistoriadelapublicidad.com/prota gonista-1050/philip-kotler. Consulta: 19 de septiembre de 2019

Roa, U. M., \& Estrada, E. V. C. (2021). Conectados-desconectados: el impacto de los derechos a la conexión y desconexión digital en las relaciones jurídicas familiares $y$ laborales.(Connecteddisconnected: the impact of the rights to digital connection and disconnection in family and labor legal relationships.). Universos Jurídicos, 1(16), 116152. 
Rodríguez J. (2019). Fundamentos del Marketing. Recuperado de: https://www.marketinginteli.com/documentosmarketing/fundamentosdemarketing/definici\% C3\%B3n-de-marketing/. Recuperado: 21 de septiembre de 2019

S/A. (2019). Marketing Social. Recuperado de: catarina.udlap.mx > tales > documentos > lmk >jimenez_t_da > capitulo4. Consulta: 20 de septiembre de 2019

Valencia Farfán, J. J. (2021). Rediseño del plan estratégico, cultura organizacional y componentes de retribución para generar compromiso en el entorno laboral de Rapientrega SA. 